\title{
Water sorption isotherms of globe artichoke leaves
}

\author{
Luis Mayor ${ }^{1}$, Alejandro Calvo ${ }^{1}$, Ramon Moreira ${ }^{2}$, Pedro Fito ${ }^{1}$, Esperanza Garcia-Castello ${ }^{1^{*}}$ \\ ${ }^{1}$ Instituto Universitario de Ingeniería de Alimentos para el Desarrollo, Universitat Politécnica de València, Camino de Vera s/n, \\ 46022 Valencia, Spain; ${ }^{*}$ Corresponding Author: egarcia1@iqn.upv.es \\ ${ }^{2}$ Departamento de Enxeñaría Química, Universidade de Santiago de Compostela, Rúa Lope Gómez de Marzoa s/n, E-15782 Santiago \\ de Compostela, Spain
}

Received August 2013

\begin{abstract}
One third of the artichoke production is used in industrial processes, where up to $70 \%-85 \%$ of the initial raw material is transformed into solid wastes. For an adequate management of these wastes, it is necessary to know their water sorption properties, because physical, chemical and biological changes which occur during their storage depend on water-solid interactions. The objectives of this work are to experimentally determine equilibrium sorption (adsorption and desorption) data of artichoke wastes at different temperatures $\left(25^{\circ} \mathrm{C}-55^{\circ} \mathrm{C}\right)$, as well as correlate and predict water sorption isotherms using bibliographic models. Equilibrium moisture content ranged $0-0.6 \mathrm{~kg}$ water $/ \mathrm{kg}$ dry solid (water activity $0.05-0.9$ ). Water sorption isotherms were classified between Types II and III. Hysteresis phenomenon was not observed, neither was the dependence of the equilibrium data with temperature. BET, GAB, Oswin and Peleg correlation models were satisfactorily fitted to experimental data. A predictive model based on composition and physical state of artichoke waste components was also successfully used to reproduce experimental data.
\end{abstract}

Keywords: Food Waste; Modeling; Moisture; Water Activity

\section{INTRODUCTION}

Artichoke (Cynara scolymus L.) is an herbaceous plant from the Astaraceae family originally from the Mediterranean area, although currently is cultivated and consumed worldwide. The edible part is its unripe inflorescence. The most appreciated parts are the soft internal leaves and the fleshy parts of its centre, and both parts together are called artichoke hearts.

One third of the artichoke production is used in indus- trial processes, mainly for the production of canned or frozen artichoke hearts [1]. In both processes, food wastes make up to $70 \%-85 \%$ of the initial raw material [2]. These wastes, made up of defective raw artichokes and above all stems and external leaves, present management problems. As high moisture organic materials are perfect substrate for fermentations or for the development of insects and rodents. By the other hand, the cost of their transportation is expensive due to their high moisture content. Currently these wastes are used for animal feed, although other alternatives are also compost production [2], methane [3] and bioalcohol production [4]. There are also other less explored possibilities, i.e. the extraction of functional compounds such as inulin and phenolics [5]. These compounds, extracted and purified, can be used as raw material for other industrial processes.

For an adequate management and valorization of these wastes, it is necessary to know their water sorption isotherms. These are plots of the equilibrium moisture content $(\mathrm{X}, \mathrm{kg}$ water $/ \mathrm{kg}$ dry solid $(\mathrm{ds}))$ vs. water activity $\left(\mathrm{a}_{\mathrm{w}}\right)$ at a certain temperature and pressure. Moisture content and water activity data are important to evaluate the physical, chemical and biological changes which occur during processing and storage of biomaterials [6] in processes where water transfer exists, such as drying, packaging and rehydration of dehydrated products [7]. In this context, the knowledge of the water sorption isotherms of artichoke wastes will provide very useful information to select the best conditions of their storage. It will also be useful in the design and optimization of valorization processes where water removal is involved, such as drying.

Furthermore, it will be of interest to obtain, within the studied temperature and water activity ranges, mathematical models that relate water activity with moisture content and temperature. For this purpose are usually employed empirical or semi-empirical equations, being the parameters of these equations obtained through the fitting of experimental data. Examples of these correlation models are the BET model [8], the GAB model [9] and others [10-14]. Recently, some models have arisen 
that allow predicting food water sorption isotherms from the chemical composition. These models use the Ross equation [15] and account for the multiphasic nature of food systems $[6,16]$.

The objectives of this work were to experimentally determine sorption (adsorption and desorption) isotherms of artichoke wastes (external leaves) at different temperatures, as well as obtain water sorption isotherms through different models from the literature. For the last purpose, correlation models as well as those based on the food chemical composition were used.

\section{MATERIALS AND METHODS}

\subsection{Sample Preparation}

Artichokes (Cynara scolymus L, "Blanca de Tudela" variety) were purchased in a local market, selecting those with similar color, size and compactness. Then they were stored in hermetic containers at $5^{\circ} \mathrm{C}$ until use. Previously to the experiments, artichokes were separated in their different parts: stem, fleshy centre, internal and external leaves. External leaves were used as solid waste since they are $90 \%$ in weight of the total solid wastes.

\subsection{Proximate Composition}

\subsubsection{Moisture Content}

Moisture content, X, was calculated by determining sample mass before and after dehydration in a vacuum oven (Vaciotem-T, SELECTA) at $60^{\circ} \mathrm{C}$ and less than 13 $\mathrm{kPa}$ till constant weight. Determinations were performed in triplicate.

\subsubsection{Reducing Sugars and Inulin}

Dehydrated leaves were ground (GVX 242, KRUPS) and $5 \mathrm{~g}$ of fine powder were extracted in $500 \mathrm{~mL}$ of water during $100 \mathrm{~min}$ at $80^{\circ} \mathrm{C}$ [17]. The filtered extract was diluted and analyzed for reducing sugars (glucose, fructose and sucrose) content by ionic chromatography (Metrosep carb 1250/4.6 column, Ion Analysis cromatograph, Methrom). Inulin was indirectly calculated by determining reducing sugars content in the filtered extract before and after acidic hydrolysis [18]. Inulin content was given by the following equation:

$$
\text { Inulin }\left(\frac{\mathrm{mg} \text { eq fructose }}{\mathrm{L} \text { extract }}\right)=0.9\left(\Delta \text { fructose }-\frac{\Delta \text { sucrose }}{2}\right)
$$

where $\Delta$ fructose $(\mathrm{mg} / \mathrm{L})$ is the increase of fructose and $\Delta$ sucrose $(\mathrm{mg} / \mathrm{L})$ is the decrease of sucrose after hydrolisis. 0.9 is a constant for the conversion of hydrated fructose to anhidrofructose [19].

\subsubsection{Other Proximal Components from Food Composition databases}

Protein, fat, insoluble fiber and inorganic salts were determined by consulting food composition databases from the literature. The consulted food databases were: National Nutrient Database for Standard Reference [20], Danish Food Composition Databank [21] and Spanish Food Composition Database [22].

\subsection{Water Sorption Isotherms}

Equilibrium moisture content of artichoke leaves at different water activities and temperatures $\left(25^{\circ} \mathrm{C}, 35^{\circ} \mathrm{C}\right.$, $45^{\circ} \mathrm{C}$ and $55^{\circ} \mathrm{C}$ ) were determined by the static method [23]. All determinations were performed in triplicate using ca. $1.5 \mathrm{~g}$ of fresh leaves for the desorption isotherms and 0.5 of freeze-dried leaves (LyoAlfa 6/-50, Telstar) for the adsorption isotherms. Determinations were performed in a range of water activity from 0.05 to 0.90 using different saturated saline solutions. Selected salts were $\mathrm{KOH}, \mathrm{LiCl}, \mathrm{MgCl}_{2}, \mathrm{~K}_{2} \mathrm{CO}_{3}, \mathrm{Mg}\left(\mathrm{NO}_{3}\right)_{2}, \mathrm{NH}_{4} \mathrm{NO}_{3}$, $\mathrm{NaCl}, \mathrm{KCl}$ and $\mathrm{BaCl}_{2}$. Each saturated solution was introduced in a hermetic container, along with vials containing the sample. For water activities above 0.65 a vial with thymol was also introduced to avoid microbial growth. Closed containers were introduced in an oven (Conterm 2000201, JP selecta) at the selected temperature. Equilibrium between samples and their environment was attained when weight variations measured each 7 days were lower than that $0.1 \%$. Moisture content of equilibrated samples was determined as described in 2.2.1.

\subsection{Sorption Isotherms Modeling}

\subsubsection{Correlation Models}

Bibliographic models with different number of parameters were selected for the fitting sorption data. The models are as follows:

- BET [8]

$$
X=\frac{a \cdot b \cdot a_{w}}{\left(1-a_{w}\right) \cdot\left[1+(b-1) \cdot a_{w}\right]}
$$

- GAB [9]

$$
X=\frac{a \cdot b \cdot c \cdot a_{w}}{\left(1-c \cdot a_{w}\right) \cdot\left(1+(b-1) \cdot c \cdot a_{w}\right)}
$$

- Halsey [10]

$$
X=\left[\frac{-a}{\ln a_{w}}\right]^{\frac{1}{b}}
$$

- Henderson [11]

$$
X=\left[\frac{\ln \left(1-a_{w}\right)}{a}\right]^{\frac{1}{b}}
$$




$$
X=a\left(\frac{a_{w}}{1-a_{w}}\right)^{b}
$$

- Peleg [13]

$$
X=a\left(a_{w}\right)^{b}+c\left(a_{w}\right)^{d}
$$

- Smith [14]

$$
X=a-b \cdot \ln \left(1-a_{w}\right)
$$

The fitting of these models to the experimental data was performed through the nonlinear optimization tool Solver of Excel 2007 (Microsoft, Redmond, WA, USA).

\subsubsection{Predictive Model Based on Food Composition}

For simplification in the calculations only the proximal composition of the artichoke leaves was used: soluble sugars (glucose, fructose and sucrose), inulin, proteins, insoluble fiber (as cellulose) and soluble inorganic salts (as $\mathrm{KCl}$ ). In this algorithm, previously described in detail [6], water activity of the food material is determined as the product of the water activity of each component, assuming that each component has an independent behavior and considering their solubilities in water. Water activity of soluble compounds was determined in the case of non-electrolitic compounds (glucose, fructose and sucrose) by the Norrish equation [24] and for electrolytic compounds by the Pitzer equation [25]. Water activity of non-soluble compounds (fiber, protein, inulin) and nonsolubilized fraction of solubles (sugars and $\mathrm{KCl}$ ) was determined through water sorption isotherms from the literature [26,27]. To simplify the model it was considered that in the studied temperature range sugar sorption isotherms are constant. Solubility was calculated through specific equations for each soluble component [16].

The prediction algorithm consists in an iterative process started with a supposed water activity value for insoluble compounds and food equilibrium moisture content. Then for this moisture content it is determined the fraction of soluble compounds, and water activity of soluble and insoluble compounds are calculated at each step according to the following convergence criteria: a) $a_{w}$ of soluble compounds $\geq a_{w}$ of insoluble compounds; $b$ ) if $a_{w}$ of soluble compounds $<$ initially supposed $a_{w}$ for insoluble compounds, then it is necessary to add an amount of water till both water activities are equal.

Finally, the results of the application of the algorithm are pairs of data water activity and its corresponding equilibrium moisture content. The algorithm has to be repeated as times as pairs of data are required to build the sorption isotherm. All calculations were performed through the software Excel 2007.

\subsection{Statistical Analysis}

Experimental sorption data shown were the average value of three experimental determinations. Goodness of fit of the models was evaluated by the following parameters: mean relative deviation $(\mathrm{E})$, median of the relative deviations, coefficient of determination $\left(\mathrm{R}^{2}\right)$ and the root mean square deviation $\left(E_{R M S}\right)$ :

$$
\begin{gathered}
E=\frac{100}{N} \sum_{i=1}^{N} \frac{\left|X_{i}^{\text {cal }}-X_{i}^{\exp }\right|}{X_{i}^{\exp }} \\
E_{R M S}=\left[\frac{1}{N} \sum_{i=1}^{N}\left(X_{\text {exp }}-X_{c a l}\right)^{2}\right]^{1 / 2}
\end{gathered}
$$

Where $X_{i}^{\text {cal }} y X_{i}^{\exp }$ are the calculated and experimental moisture content values, respectively, and $\mathrm{N}$ is the number of experimental data. Calculations were performed with the Excel 2007 software.

\section{RESULTS AND DISCUSSION}

\subsection{Proximal Composition of Artichoke External Leaves}

Table 1 shows the proximal composition of artichoke wastes (external leaves), obtained from moisture content, sugars and inulin determinations, as well as information of food composition databases.

Data from Table 1 were obtained as follows: a) Moisture content was determined experimentally; b) reducing sugars and inulin were also experimentally determined; c) protein, fat and inorganic salts are the average values of the three consulted food composition databases. Since potassium is by far the main inorganic cation, inorganic salts are given in $\mathrm{KCl}$ equivalents. This simplification makes easier the use of the model described in 2.4 .2 ; d) finally, cellulose as insoluble fiber was obtained through a mass balance between total solids content and the other proximal components calculated previously.

Table 1. Proximal composition of artichoke external leaves.

\begin{tabular}{ccc}
\hline Component & $\%$ (wet basis) & $\%$ (dry basis) \\
\hline Water & 83.74 & - \\
Protein & 3.16 & 19.41 \\
Insoluble fiber (cellulose) & 8.74 & 53.78 \\
Inulin & 1.93 & 11.86 \\
Fat & 0.18 & 1.13 \\
Inorganic salts (KCl) & 1.02 & 6.27 \\
Glucose & 0.23 & 1.41 \\
Fructose & 0.51 & 3.12 \\
Sucrose & 0.49 & 3.00 \\
\hline
\end{tabular}


Protein, fat, inorganic salts and fiber are an approximation to the real values, since they have been obtained from food databases. Furthermore, in these tables the values are for the whole artichoke.

\subsection{Sorption Isotherms}

Figure 1 shows experimental sorption data of artichoke external leaves at different temperatures. Moisture content for each water activity is the average of three replicates.

It is observed a similar trend for all the isotherms; moisture content increases with water activity progressively, very smoothly at low moisture contents and asymptotically from water activity of 0.8 . For this, isotherms show a slightly sigmoid shape between types II and III proposed by IUPAC [28]. Equilibrium moisture content ranged $0-0.6 \mathrm{~kg}$ water $/ \mathrm{kg}$ ds. Both shape of isotherms and equilibrium moisture content ranges are similar to other food products such as pumpkin [29], pepper [30] and garlic [31].

It can be also observed that adsorption and desorption isotherms are overlapped, indicating that hysteresis is not produced. This phenomenon is observed as a displacement between adsorption and desorption isotherms, being the last one above the first. The hysteresis is consequence of irreversible phenomena of conformational and structural rearrangements, which alter the accessibility of energetically favorable polar sites and thus may hinder the movement of moisture [32]. It is well known that freeze-drying is a dehydration process where the structural collapse is minimized, leading to products with high rehydration capability [33]; then the use of this drying technique in the preparation of samples for the adsorption experiments may have influenced on the absence of hysteresis.

An effect of temperature on the water sorption isotherms is not observed, indicating that the external artichoke leaves show similar hygroscopicities within the studied temperature range $\left(25^{\circ} \mathrm{C}-55^{\circ} \mathrm{C}\right)$. The effect of temperature is more evident at higher temperatures and wider ranges. At moderate temperatures less physical and chemical changes are promoted, and the attained energy levels do not allow significant water mobility changes. This behavior at moderate temperatures has been ob-
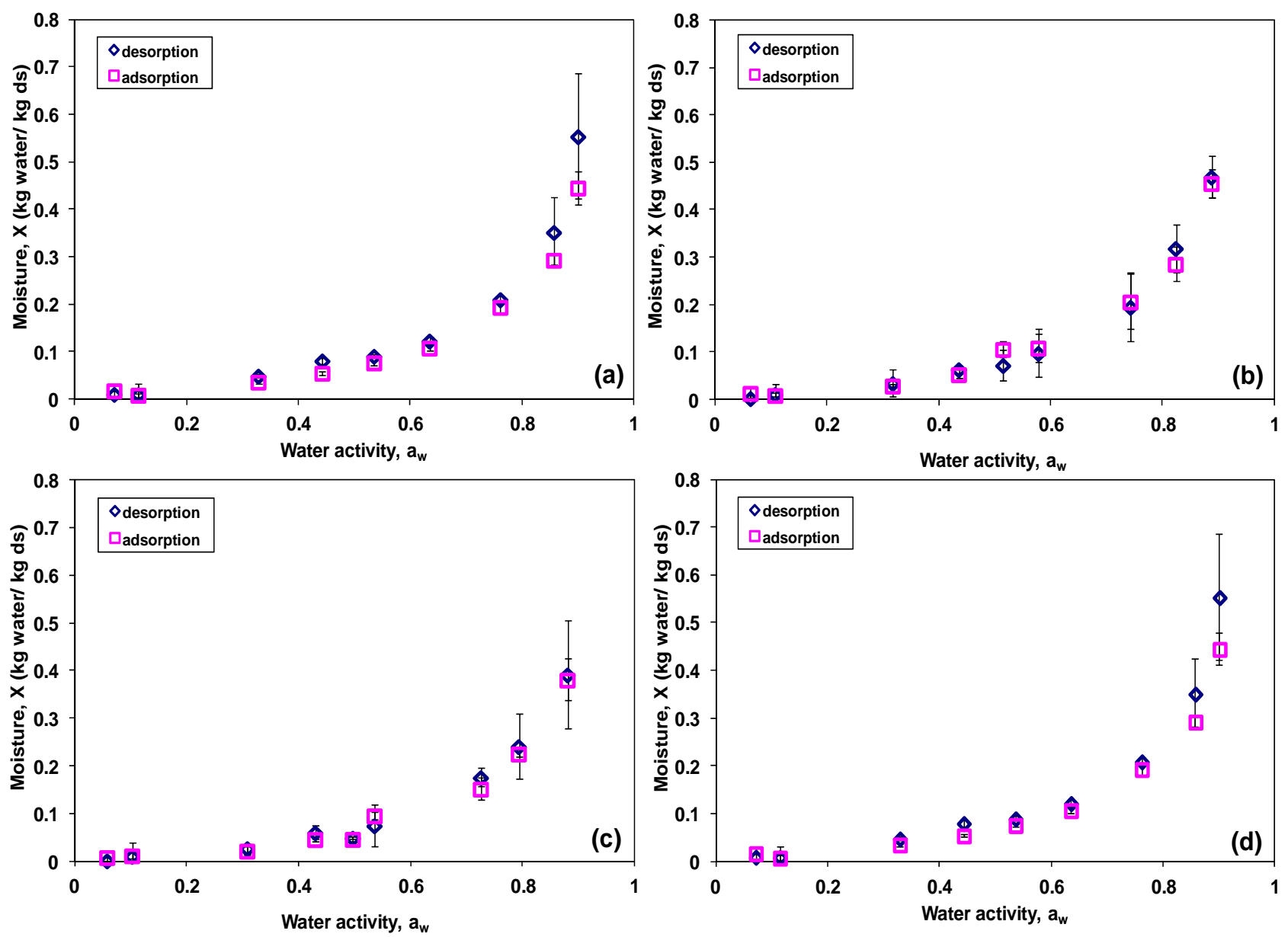

Figure 1. Water sorption isotherms for artichoke external leaves: (a) $25^{\circ} \mathrm{C}$; (b) $35^{\circ} \mathrm{C}$; (d) $45^{\circ} \mathrm{C}$; (e) $55^{\circ} \mathrm{C}$. 
served by other authors for pumpkin [29] and sweet potato [34]. Since sorption properties are not temperature dependent, external artichoke leaves can be stored in the same atmosphere at any temperature within the studied range. In addition, experimental data obtained at different temperatures were used together for modeling purposes.

\subsection{Water Sorption Isotherms Modeling}

\subsubsection{Correlation Models}

Figure 2 shows water sorption (adsorption and desorption) data at all the studied temperatures, as well as the sorption isotherms obtained with the selected correlation models. The fit of the models to experimental data is adequate, although Halsey and Smith models show higher deviations at high water activities $(0.8-0.9)$.

Table 2 shows the calculated parameters after fitting and the goodness of fit of the models. Those with better fits (lower $E$, median and $E_{R M S}$ values and higher $\mathrm{R}^{2}$ ) are BET, GAB, Oswin and Peleg, all of them with similar values for these parameters.

$E$ values are relatively high, mainly due to the high deviations at low moisture contents $(\mathrm{X}<0.1)$. Medians of the deviations and determination coefficients show that the fits of the models are adequate, above all considering that fits have been performed with adsorption and desorption data at different temperatures together (wide application range of the models).

BET and GAB models can be selected for modeling purposes because the physical meaning of their parameters [29], as well as Oswin model because of its simplicity. Specifically for the GAB model the "a" parameter is $0.075 \mathrm{~kg}$ water $/ \mathrm{kg} \mathrm{ds}$, and corresponds to the monolayer moisture content, an important value for the selection of the storage conditions of the artichoke leaves.

\subsubsection{Predictive Model Based on Food Composition}

The application of the predictive model (Figure 3) at different temperatures corroborates the no significant temperature effect on the sorption isotherms in the studied temperature range, as observed experimentally.

It is also observed that the predictive model evaluated at $40^{\circ} \mathrm{C}$ (average temperature) gives acceptable results regarding the shape of the water sorption isotherm. Nevertheless, predicted equilibrium moisture content is systematically higher than experimental data. This result can be explained based on the use of bibliographic composition data (protein, fat, salts and fiber) for whole artichoke instead of data for artichoke leaves, since the last were not available.

In spite of this, statistical data $\mathrm{E}=47.9 \%$, median of deviations $=30.7 \%, E_{R M S}=0.060$ and $\mathrm{R}^{2}=0.96$ are within the range given by the correlation models.

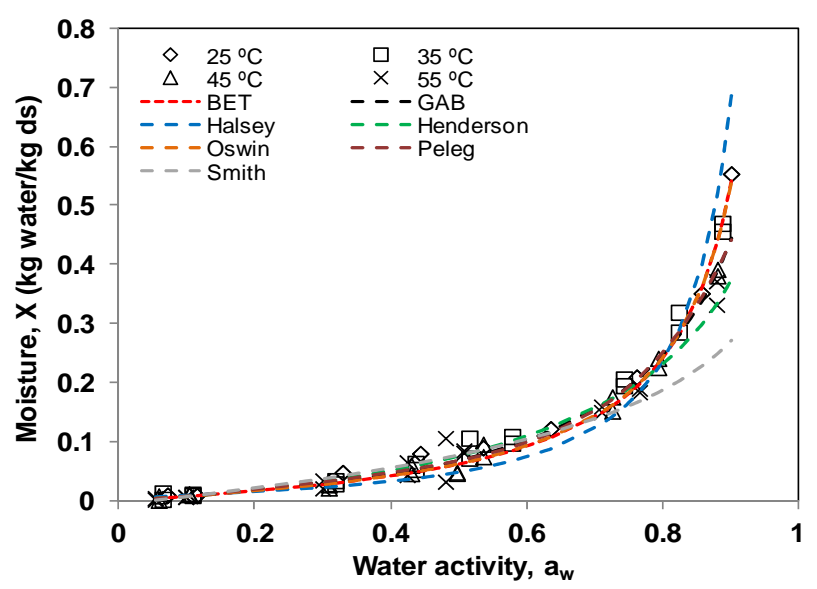

Figure 2. Experimental sorption data (dots) and sorption isotherms (lines) obtained with the selected correlation models.

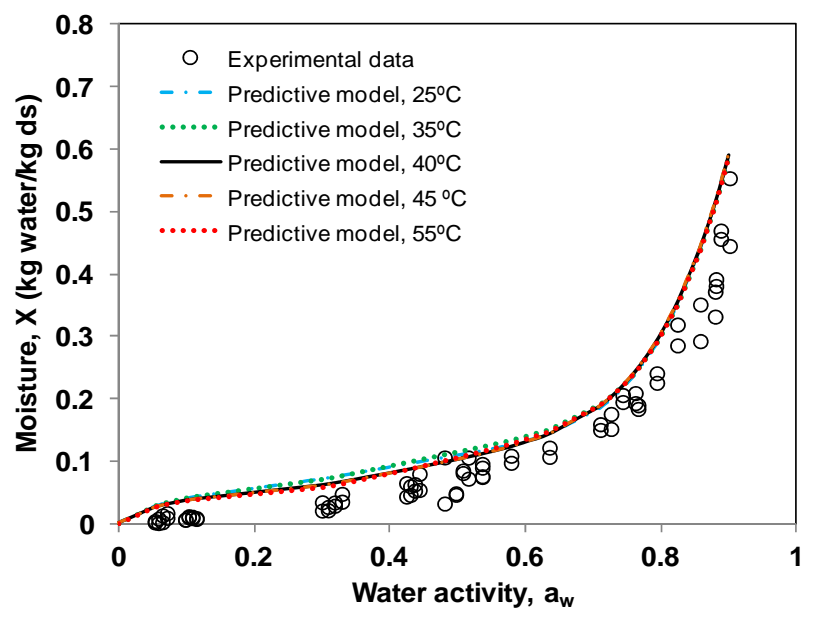

Figure 3. Experimental sorption data (dots) and sorption isotherms (lines) obtained with the prediction model.

Table 2. Correlation models: calculated constants after model fitting and goodness of fit statistics.

\begin{tabular}{|c|c|c|c|c|c|c|c|c|}
\hline \multirow{2}{*}{ Model } & \multicolumn{4}{|c|}{ Fitting constants } & \multicolumn{4}{|c|}{ Statistics } \\
\hline & $\mathrm{a}$ & $\mathrm{b}$ & $\mathrm{c}$ & $\mathrm{d}$ & $E(\%)$ & Median of dev. (\%) & $\mathrm{R}^{2}$ & $E_{R M S}$ \\
\hline BET & 0.059 & 1.103 & - & - & 21.52 & 14.74 & 0.97 & 0.026 \\
\hline GAB & 0.075 & 0.995 & 0.947 & - & 20.96 & 10.75 & 0.98 & 0.025 \\
\hline Halsey & 0.080 & 0.713 & - & - & 33.62 & 26.13 & 0.93 & 0.057 \\
\hline Hendersopn & -4.819 & 0.748 & - & - & 21.87 & 13.63 & 0.96 & 0.035 \\
\hline Oswin & 0.063 & 0.975 & - & - & 21.50 & 14.14 & 0.97 & 0.026 \\
\hline Peleg & 0.622 & 6.958 & 0.161 & 1.375 & 19.88 & 13.26 & 0.97 & 0.023 \\
\hline Smith & -0.005 & 0.120 & - & - & 27.66 & 20.13 & 0.88 & 0.066 \\
\hline
\end{tabular}




\section{CONCLUSIONS}

The shape of the sorption isotherms of artichoke leaves was between types II and III (slight sigmoidal curve).

Within the studied temperature range, hysteresis phenomenon was not observed, neither was the equilibrium data dependence on temperature.

BET, GAB, Oswin and Peleg correlation models were satisfactorily fitted to experimental data. The predictive model based on composition and physical state of artichoke waste components was also successfully used to reproduce experimental values. An advantage of this last model is its independence of experimental water sorption values to obtain predicted data and experimental time saving.

\section{ACKNOWLEDGEMENTS}

Author Luis Mayor acknowledges JCI2009-04923 grant to MINECO (Spain).

\section{REFERENCES}

[1] Arthey, D. and Dennis, C. (1992) Procesado de hortalizas. Editorial Acribia, Zaragoza.

[2] Rodriguez Lopez, J.N. (2009) Aprovechamiento de Residuos de alcachofa. http://hdl.handle.net/10201/6303

[3] Mata, J. (1998) Plantas de biometanización para la fracción orgánica de los RSU: II Tecnologías. Residuos, 42, 72-75.

[4] Lázaro, L. and Arauzo, J. (1994) Aprovechamiento de residuos de la industria de conservas vegetales. Hidrólisis enzimática, 12, 227-240.

[5] Lattanzio, V., Kroon, P.A., Linsalata, V. and Cardinali, A. (2009) Globe artichoke: A functional food and source of nutraceutical ingredients. Journal of Functional Foods, 1, 131-144. http://dx.doi.org/10.1016/j.jff.2009.01.002

[6] Moreira, R., Chenlo, F. and Torres, M.D. (2009) Simplified algorithm for the prediction of water sorption isotherms of fruits, vegetables and legumes based upon chemical composition. Journal of Food Engineering, 94, 334-343. http://dx.doi.org/10.1016/j.jfoodeng.2009.03.026

[7] Singh, R.P. and Heldman, D.R. (1993) Introduction to food engineering. 2nd Edition, Academic Ress. Inc., San Diego.

[8] Brunauer, S., Emmett, P.H. and Teller, E. (1938) Adsorption of gases in multimolecular layers. Journal of the American Chemical Society, 60, 309-319. http://dx.doi.org/10.1021/ja01269a023

[9] Van der Berg, C. and Bruin, S. (1981) Water activity and its estimation in food systems. In: Rockland, L.B. and Stewarts, G.F., Eds., Theorical Aspects in Water Activity: Influence on Food Quality, Academic Press, New York, $12-45$.

[10] Halsey, G. (1948) Physical adsorption on non-uniform surfaces. Journal of Chemical Physics, 16, 931-937. http://dx.doi.org/10.1063/1.1746689

[11] Henderson, S.M. (1952) A basic concept of equilibrium moisture. Agricultural Engineering, 33, 29-32.

[12] Oswin, G.R. (1946) The kinetics of package life. International Chemical Industry, 65, 419-421.

http://dx.doi.org/10.1002/jctb.5000651216

[13] Peleg, M. (1993) Assessment of a semi-empirical four parameter general model for sigmoid moisture sorption isotherms. Journal of Food Process Engineering, 16, 2137. http://dx.doi.org/10.1111/j.1745-4530.1993.tb00160.x

[14] Smith, S. E. (1947) The sorption of water vapour by high polymers. Journal of the American Chemical Society, 69, 646-651. http://dx.doi.org/10.1021/ja01195a053

[15] Ross, K. D. (1975) Estimation of water activity in intermediate moisture foods. Food Technology, 3, 26-34.

[16] Roman, A.D., Herman-y-Lara, E., Salgado-Cervantes, M. A. and García-Alvarado, M.A. (2004) Food sorption isotherms prediction using the Ross equation. Drying Technology, 22, 1829-1843. http://dx.doi.org/10.1081/DRT-200032802

[17] Dubois, M., Gilles, K.A., Hamilton, J.K., Rebers, P.A. and Smith, F. (1956) Colorimetric method for determination of sugars and related substances. Analytical Chemistry, 28, 350-356. http://dx.doi.org/10.1021/ac60111a017

[18] Saengkanuk, A., Nuchadomrong, S., Jogloy, S., Patanothai, A. and Srijaranai, S. (2011) A simplified spectrophotometric method for the determination of inulin in Jerusalem artichoke (Helianthus tuberosus L.) tubers. European Food Research \& Technology, 233, 609-616. http://dx.doi.org/10.1007/s00217-011-1552-3

[19] McCleary, B.V., Murphy, A. and Mugford, D.C. (2000) Measurement of total fructan in foods by enzymatic/ spectrophotometric method: Collaborative study. Journal of AOAC International, 83, 356-364.

[20] United States Department of Agriculture (2013) National nutrient database for standard reference. http://ndb.nal.usda.gov

[21] Danish National Food Institution (2013) Danish food composition databank. http://www.foodcomp.dk

[22] Spanish Agency of Food Safety and Nutrition (2013) Spanish database of food composition. http://www.bedca.net

[23] Wolf, W., Spiess, W.E.L. and Jung, G. (1985) Standardization of isotherm measurements (Cost project 90 and 90 bis). In Simatos, D. and Multon, J.L., Eds., Properties of Water in Foods, Martinus Nijhoff, Dordrecht, 661-679. http://dx.doi.org/10.1007/978-94-009-5103-7 40

[24] Norrish, R.S. (1966) An equation for the activity coefficients and equilibrium relative humidities of water in confectionary syrups. Journal of Food Technology, 1, 2539. http://dx.doi.org/10.1111/j.1365-2621.1966.tb01027.x

[25] Pitzer, K.S. (1973) Electron repulsion integrals and symmetry adapted charge distributions. Journal of Chemical Physics, 59, 3308-3312. http://dx.doi.org/10.1063/1.1680474

[26] Salgado, M.A., Garcia, M.A. and Waliszewski, K.N. (1994) Modeling of water activity and enthalpy of water sorption 
in cassava chips. Drying Technology, 12, 1743-1752. http://dx.doi.org/10.1080/07373939408962197

[27] Makower, B. and Dye, W.B. (1956) Equilibrium moisture content and crystallisation of amorphous sucrose and glucose. Journal of Agriculture and Food Chemistry, 4, 72-77. http://dx.doi.org/10.1021/jf60059a010

[28] Sing, K.S.W., Everett, D.H., Haul, R.A.W., Moscou, L., Pierotti, R.A., Rouquerol, J. and Siemienievwska, T. (1985) Reporting physisorption data for gas/solid systems. Pure Applied Chemistry, 57, 603-619. http://dx.doi.org/10.1351/pac198557040603

[29] Mayor, L., Moreira, R., Chenlo, F. and Sereno, A.M. (2005) Water sorption isotherms of fresh and partially osmotic dehydrated pumpkin parenchyma and seeds at several temperatures. European Food Research and Technology, 220, 163-167. http://dx.doi.org/10.1007/s00217-004-1065-4

[30] Chenlo, F., Moreira, R., Chaguri, L. and Santos, F. (2005) Desorption isotherms of Padron peppers (Capsicum an- nuum L. Var Longum). Ciencia y Tecnología Alimentaria, $5,18-24$

[31] Vázquez, G., Chenlo, F., Moreira, R. and Costoyas, A. (1999) The dehydration of garlic. 1. Desorption isotherms and modelling of drying kinetics. Drying Technology, 17, 1095-1108.

http://dx.doi.org/10.1080/07373939908917596

[32] Rizvi, S. S. (2005) Thermodynamic properties of foods in dehydration. In: Rao, M.A., Rizvi, S.S.H. and Datta A.K. Eds., Engineering properties of foods, 3rd Edition, Taylor \& Francis, Boca Ratón, 259-346. http://dx.doi.org/10.1201/9781420028805.ch7

[33] Lin, T.M., Durance, T.D. and Scaman, C.H. (1998) Characterization of vacuum microwave, air and freeze dried carrot slices. Food Research International, 31, 111-117. http://dx.doi.org/10.1016/S0963-9969(98)00070-2

[34] Chen, C. (2002) Sorption isotherms of sweet potato slices. Biosystems Engineering, 83, 85-95. http://dx.doi.org/10.1006/bioe.2002.0093 